\title{
The etiological features of anterior uveitis in a Turkish population
}

This article was published in the following Dove Press journal:

Clinical Ophthalmology

30 May 2012

Number of times this article has been viewed

\author{
Esra Guney \\ Betul Ilkay Sezgin Akcay \\ Gurkan Erdogan \\ Cihan Unlu \\ Gulunay Akcali \\ Huseyin Bayramlar \\ Ophthalmology Clinic, Umraniye \\ Research and Training Hospital, \\ Istanbul, Turkey
}

Correspondence: Esra Guney Umraniye Egitim ve Arastirma Hastanesi, Goz Klinigi, Istanbul, Turkey

Tel +90 5327752554

Fax +90 216 632 7I 24

Email esraguney@yahoo.com
Purpose: To identify any patterns in the cause of anterior uveitis in a Turkish population and compare them with results from previous studies.

Methods: The clinical records of 75 patients between January 2009 and January 2010 were retrospectively analyzed and classified as anterior uveitis according to Standardization of Uveitis Nomenclature criteria. Complete blood count, sedimentation rate, chest radiography, purified protein derivative skin test, and venereal disease research laboratory test were done on all patients. Additional serologic and radiographic tests were performed when indicated.

Results: Forty-one (54.6\%) were male and 34 (45.3\%) were female patients. The mean age at presentation was $39.1 \pm 12.6$ years. Fifty-six $(74.6 \%)$ had unilateral and $19(25.3 \%)$ had bilateral disease at presentation. A specific diagnosis was able to be established in 54 (72\%) patients. The most common diagnoses were anterior uveitis associated with human leukocyte antigen B27 (14.6\%) and Fuchs uveitis syndrome (14.6\%). The second most common diagnosis was uveitis associated with herpes simplex virus (13.3\%), followed by Behcet's uveitis $(6.6 \%)$. Systemic disease associations were noted in $15(20 \%)$ patients, and the most commonly associated systemic disease was Behcet's disease (6.6\%).

Conclusion: Fuchs uveitis syndrome and anterior uveitis associated with human leukocyte antigen B27 were the most common form of anterior uveitis in this study. Using a systematic approach, a diagnosis was able to be established in $72 \%$ of the anterior uveitis cases.

Keywords: anterior uveitis, differential diagnosis, etiology, laboratory investigations

\section{Introduction}

Anterior uveitis is the most common form of uveitis. ${ }^{1}$ Although anterior uveitis is usually the most easily managed form of uveitis, associated complications such as cataract, glaucoma, and cystoid macular edema may result in severe visual loss. Several studies have reported different referral patterns of anterior uveitis in different countries..$^{2-8}$ In order to identify specific ocular and systemic conditions and decide on treatment strategies, diagnosis of anterior uveitis is essential. With a systematic approach, diagnoses can be established in up to $70 \%$ of cases. ${ }^{9}$

The purpose of this study was to identify any patterns in the cause of anterior uveitis compared with results from previous studies.

\section{Materials and methods}

In the uveitis department of the Ophthalmology Clinic at Umraniye Research and Training Hospital (Istanbul, Turkey), the clinical records of all anterior uveitis patients between January 2009 and January 2010 were analyzed retrospectively. Each patient 
underwent a complete ophthalmic examination including best corrected visual acuity (Snellen scale), slit lamp bio microscopy, tonometry, and indirect ophthalmoscopy. Age at presentation, gender, previous ophthalmologic examination, and systemic disease association were recorded for all patients.

Laboratory investigations including complete blood count, sedimentation rate, chest radiography, purified protein derivative skin test, and venereal disease research laboratory test were done on all patients. Additional serologic and radiographic tests such as sacroiliac spine X-rays or thorax computed tomography were performed when indicated. In patients presented with nongranulomatous uveitis, human leukocyte antigen (HLA)-B27 typing, and pathergy test were performed also. HLA-B5 and HLA-B51 could not be evaluated due to financial reasons. Systemic disease associations were investigated with an internist, rheumatologist, or pulmonologist whenever it was required to document the etiological diagnosis.

Patients were classified as anterior uveitis according to the recommendations of the Standardization of Uveitis Nomenclature group. ${ }^{10}$ Patients with large "mutton-fat" keratic precipitates, Koeppe nodules, and/or Busacca nodules were classified as granulomatous uveitis. Patients who were HLA-B27 positive and proved to be negative on radiographic testing and/or rheumatologic evaluation were classified as having anterior uveitis associated with HLA-B27. The diagnosis of seronegative spondyloarthropathy was established after rheumatologic consultation. Diagnosis of Behcet's disease was made in patients fulfilling the diagnostic criteria of the International Study Group for Behcet's disease. ${ }^{11}$ The diagnosis of herpetic uveitis was based on clinical findings. The presence of herpetic or dendritic keratitis, stromal scars, edema, decreased corneal sensation, acutely elevated intraocular pressure, or sectoral iris atrophy with unilateral uveitis were the strongest diagnostic findings. ${ }^{12}$

The diagnosis of Fuchs uveitis syndrome (FUS) was established by the constellation of clinical findings also. These findings were diffuse, small to medium sized keratic precipitates, chronic low grade anterior chamber reaction, diffuse iris stromal atrophy, lack of posterior synechia, and the absence of cystoid macular edema, retinal vasculitis, snowbanks, and chorioretinal infiltrates despite the presence of vitreous cells and debris. ${ }^{13}$ The diagnosis of bilateral acute depigmentation of the iris (BADI) was based on ocular findings including an acute onset of bilateral symmetrical depigmentation of the iris stroma, pigment discharge into the anterior chamber, and pigment accumulation in the trabecular meshwork. ${ }^{14}$
The clinical diagnosis of sarcoidosis was made using the criteria proposed by the International Workshop on Ocular Sarcoidosis. ${ }^{15}$ The diagnosis of the patients was confirmed by transbronchial lung biopsy and classified as "definite sarcoidosis."

Patients in which a specific diagnosis could not be made were classified as "undetermined."

Informed consent was obtained from all patients.

\section{Results}

In a 1 -year period, there were 131 cases of uveitis - with an incidence of $0.4 \%$ - among 32,468 new cases that were seen at the authors' clinic. Of those 131 patients, 75 (57.5\%) were diagnosed as anterior uveitis, 27 (20.6\%) were diagnosed as panuveitis, 18 (13.7\%) were diagnosed as posterior uveitis, and eleven (8.3\%) were diagnosed as intermediate uveitis. All patients were Turkish Caucasians. Of the 75 patients included in the study, $61(81.3 \%)$ patients were seen in the authors' clinic, nine $(12 \%)$ were referred from other disciplines at the hospital with an established systemic diagnosis, and five $(6.6 \%)$ were seen by an ophthalmologist before referral. Forty-one (54.6\%) were male and $34(45.3 \%)$ were female patients. The male to female ratio was $1.2: 1$. The mean age at presentation was $39.1 \pm 12.6$ years; $64(85.3 \%)$ were aged $20-60$ years. As mentioned in Table 1, 56 (74.6\%) had unilateral and $19(25.3 \%)$ had bilateral disease at presentation. A total of 94 eyes had uveitis. Nongranulomatous uveitis was seen in $70(74.4 \%)$ eyes and granulomatous uveitis was seen in $24(25.5 \%)$ eyes. Nongranulomatous uveitis was seen in $57(76 \%)$ patients and granulomatous uveitis was seen in 18 (24\%) patients. The most common granulomatous forms of anterior uveitis were FUS (25\%) and anterior uveitis associated with herpes simplex virus (HSV) (12.5\%). Twenty-five percent of the granulomatous cases were classified as undetermined. The most frequent nongranulomatous forms of uveitis were anterior uveitis associated with HLA-B27 and Behcet's disease. Anterior uveitis associated with HSV and anterior uveitis associated with varicella zoster virus

Table I Age and sex distribution of anterior uveitis

\begin{tabular}{llll}
\hline & Male & Female & Total \\
\hline $\begin{array}{l}\text { Number of patients } \\
\text { Age }\end{array}$ & $4 I(54.6 \%)$ & $34(45.3 \%)$ & 75 \\
$\quad$ Range & $8-59$ & $7-74$ & $7-74$ \\
$\quad \begin{array}{l}\text { Mean } \\
\text { Eye involvement }\end{array}$ & $37.3( \pm 12)$ & $4 I( \pm 12.6)$ & $39.1( \pm 12.6)$ \\
$\quad \begin{array}{l}\text { Unilateral } \\
\text { Bilateral }\end{array}$ & $35(46.6 \%)$ & $21(28 \%)$ & $56(74.6 \%)$ \\
\hline
\end{tabular}


were referred to as infectious anterior uveitis, and was diagnosed in $13(17.3 \%)$ patients.

A specific diagnosis was able to be established in $54(72 \%)$ patients. The most common diagnoses were anterior uveitis associated with HLA-B27 (14.6\%) and FUS (14.6\%). The second most common diagnosis was anterior uveitis associated with HSV (13.3\%), followed by Behcet's disease $(6.6 \%)$. All cases with BADI had bilateral disease and all cases with herpetic keratouveitis had unilateral disease (Table 2). Male predominance was obvious among patients with Behcet's disease (80\%) and FUS (72.7\%). All the patients with BADI and sarcoidosis were female, and anterior uveitis associated with HLA-B27 (63.6\%) was more common among female patients (Table 3). Systemic disease associations were noted in 15 (20\%) patients, and the most commonly associated systemic disease was Behcet's disease (6.6\%). Of the total 75 patients, 64 (85.3\%) were presented to the clinic at 16-60 years of age. Table 4 provides data on the distribution of etiology and uveitis diagnosis by age.

Visual acuity of the eyes was assessed at initial presentation (Table 5). Of the 94 eyes, eight ( $8.5 \%$ ) had visual acuity less than 20/200. The most common etiology for visual acuity

Table 2 Diagnosis of uveitis patients and distribution according to ocular involvement $(\mathrm{N}=75)$

\begin{tabular}{|c|c|c|c|c|}
\hline Diagnosis & $\begin{array}{l}\text { Number } \\
\text { (\%) of } \\
\text { patients }\end{array}$ & $\begin{array}{l}\text { Bilateral } \\
(n=19)\end{array}$ & $\begin{array}{l}\text { Unilateral } \\
(n=56)\end{array}$ & $\begin{array}{l}\text { Mean age at } \\
\text { presentation } \\
\text { (years) }\end{array}$ \\
\hline $\begin{array}{l}\mathrm{AU} \text { associated } \\
\text { with HLA-B27 }\end{array}$ & II (I4.6\%) & $I(9 \%)$ & $10(90.9 \%)$ & 41.6 \\
\hline $\begin{array}{l}\text { AU associated } \\
\text { with AS }\end{array}$ & $4(5.3 \%)$ & I (25\%) & $3(75 \%)$ & 33.2 \\
\hline $\begin{array}{l}\text { AU associated } \\
\text { with UC }\end{array}$ & I (I.3\%) & - & I (100\%) & 35 \\
\hline $\begin{array}{l}\text { AU associated } \\
\text { with psoriasis }\end{array}$ & I (I.3\%) & - & I (100\%) & 31 \\
\hline $\begin{array}{l}\text { Fuchs uveitis } \\
\text { syndrome }\end{array}$ & II (I4.6\%) & $3(27.2 \%)$ & 8 (72.7\%) & 33.8 \\
\hline $\begin{array}{l}\text { AU associated } \\
\text { with HSV }\end{array}$ & $10(13.3 \%)$ & - & $10(100 \%)$ & 41 \\
\hline $\begin{array}{l}A U \text { associated } \\
\text { with VZV }\end{array}$ & $3(4 \%)$ & - & $3(100 \%)$ & 56 \\
\hline Behcet's uveitis & $5(6.6 \%)$ & $2(40 \%)$ & $3(60 \%)$ & 29.2 \\
\hline BADI & $4(5.3 \%)$ & $4(100 \%)$ & & 38.5 \\
\hline $\begin{array}{l}\text { JIA associated } \\
\mathrm{AU}\end{array}$ & $2(2.6 \%)$ & $2(100 \%)$ & & 7.5 \\
\hline $\begin{array}{l}\text { AU associated } \\
\text { with sarcoidosis }\end{array}$ & $2(2.6 \%)$ & $2(100 \%)$ & & 36.5 \\
\hline Undetermined & $21(28 \%)$ & $4(19 \%)$ & I7 (8I\%) & 43.9 \\
\hline
\end{tabular}

Abbreviations: AU, anterior uveitis; AS, ankylosing spondylitis; BADI, bilateral acute depigmentation of the iris; HLA, human leukocyte antigen; HSV, herpes simplex virus; JIA, juvenile idiopathic arthritis; UC, ulcerative colitis; VZV, varicella zoster virus.
Table 3 Diagnosis of patients according to sex

\begin{tabular}{|c|c|c|c|}
\hline \multirow[t]{2}{*}{ Diagnosis } & \multirow{2}{*}{$\begin{array}{l}\text { Number of } \\
\text { patients } \\
(\mathbf{N}=75)\end{array}$} & \multicolumn{2}{|c|}{$\begin{array}{l}\text { Sex distribution } \\
\text { n (\%) }\end{array}$} \\
\hline & & $\begin{array}{l}\text { Male } \\
41(54.6 \%)\end{array}$ & $\begin{array}{l}\text { Female } \\
34(45.3 \%) \\
\end{array}$ \\
\hline $\begin{array}{l}\text { AU associated } \\
\text { with HLA-B27 }\end{array}$ & 11 & $4(36.3 \%)$ & 7 (63.6\%) \\
\hline $\begin{array}{l}\text { AU associated } \\
\text { with AS }\end{array}$ & 4 & $3(75 \%)$ & I (25\%) \\
\hline $\begin{array}{l}A U \text { associated } \\
\text { with UC }\end{array}$ & I & I (I00\%) & - \\
\hline $\begin{array}{l}\text { AU associated } \\
\text { with psoriasis }\end{array}$ & 1 & I (100\%) & - \\
\hline $\begin{array}{l}\text { Fuchs uveitis } \\
\text { syndrome }\end{array}$ & 11 & $8(72.7 \%)$ & $3(27.2 \%)$ \\
\hline $\begin{array}{l}\text { AU associated } \\
\text { with HSV }\end{array}$ & 10 & $5(50 \%)$ & $5(50 \%)$ \\
\hline $\begin{array}{l}\text { AU associated } \\
\text { with VZV }\end{array}$ & 3 & $3(100 \%)$ & - \\
\hline Behcet's uveitis & 5 & $4(80 \%)$ & I (20\%) \\
\hline BADI & 4 & - & $4(80 \%)$ \\
\hline JIA associated AU & 2 & I (50\%) & I (50\%) \\
\hline $\begin{array}{l}\text { AU associated } \\
\text { with sarcoidosis }\end{array}$ & 2 & - & $2(100 \%)$ \\
\hline Undetermined & 21 & II (53.4\%) & $10(47.6 \%)$ \\
\hline
\end{tabular}

Abbreviations: AU, anterior uveitis; AS, ankylosing spondylitis; BADI, bilateral acute depigmentation of the iris; HLA, human leukocyte antigen; HSV, herpes simplex virus; JIA, juvenile idiopathic arthritis; UC, ulcerative colitis; VZV, varicella zoster virus.

less than 20/200 was FUS-induced cataract and corneal scarring associated with HSV.

\section{Discussion}

In the present study, the aim was to establish the etiologic distribution of anterior uveitis. The present series mostly studied patients who attended the authors' clinic directly; only $19.7 \%$ of the patients were referrals.

A specific diagnosis was able to be established in $72 \%$ of patients, meaning the etiology remained undetermined in $28 \%$. According to different reports, diagnosis can be made in $54 \%-80 \%$ of cases with anterior uveitis..$^{3-8}$ Systemic disease associations were found in $20 \%$ of patients, of which Behcet's disease - due to the geographical distribution - comprised a great proportion. Systemic disease associations in anterior uveitis have been previously reported to be $13 \%-42 \% .{ }^{3,5-7}$

All patients were Caucasians born in Turkey. The mean age at presentation was $39.1 \pm 12.6$ years (range $7-74$ years), which is in agreement with other reports that state uveitis to be most common in the third decade of life. ${ }^{16,17}$ Males and females were almost equally represented. Unilateral nongranulomatous involvement was found to be more common. The majority of patients were aged between 16-60 years $(85.3 \%)$. Herpetic uveitis was the leading cause of anterior 
Table 4 Distribution of etiology and diagnosis of uveitis according to age

\begin{tabular}{|c|c|c|c|}
\hline \multirow[t]{2}{*}{ Diagnosis } & \multicolumn{3}{|c|}{$\begin{array}{l}\text { Age distribution } \\
\text { n (\%) }\end{array}$} \\
\hline & $<6$ years & $16-60$ years & $>60$ years \\
\hline $\begin{array}{l}\text { AU associated with } \\
\text { HLA-B27 }\end{array}$ & - & II (I7\%) & - \\
\hline AU associated with AS & - & $4(6 \%)$ & - \\
\hline$A U$ associated with UC & - & I (2\%) & - \\
\hline $\begin{array}{l}\text { AU associated with } \\
\text { psoriasis }\end{array}$ & - & I (2\%) & - \\
\hline Fuchs uveitis syndrome & - & II(I7\%) & - \\
\hline AU associated with HSV & - & $8(13 \%)$ & $2(29 \%)$ \\
\hline$A U$ associated with VZV & - & $2(3 \%)$ & I (14\%) \\
\hline Behcet's uveitis & - & $5(8 \%)$ & - \\
\hline BADI & - & $4(6 \%)$ & - \\
\hline JIA associated AU & $2(50 \%)$ & - & - \\
\hline $\begin{array}{l}\text { AU associated with } \\
\text { sarcoidosis }\end{array}$ & - & $2(3 \%)$ & - \\
\hline Undetermined & $2(50 \%)$ & 15 (23\%) & $4(57 \%)$ \\
\hline
\end{tabular}

Abbreviations: $\mathrm{AU}$, anterior uveitis; $\mathrm{AS}$, ankylosing spondylitis; BADI, bilateral acute depigmentation of the iris; HLA, human leukocyte antigen; HSV, herpes simplex virus; JIA, juvenile idiopathic arthritis; UC, ulcerative colitis; VZV, varicella zoster virus.

uveitis in patients older than 60 years. The most common diagnosis among males was FUS, and anterior uveitis associated with HLA-B27 was the most common among females. In the present series, BADI and anterior uveitis associated with sarcoidosis were predominantly seen in females, which is similar to other reports, ${ }^{3,5,6,14}$ and anterior uveitis associated with varicella zoster virus was predominantly seen in males.

In the present series, the most frequent diagnoses were anterior uveitis associated with HLA-B27 (14.6\%) and FUS, followed by anterior uveitis associated with HSV (13.3\%) and Behcet's uveitis (6.6\%). However, Behcet's disease was diagnosed in $31.3 \%$ of eyes with anterior uveitis and was the most common cause of anterior uveitis in Kazokoglu et al's recent multicenter Turkish study. ${ }^{3}$ Their high percentage of Behcet's uveitis may be explained by

Table 5 Visual acuity for the most common diagnoses

\begin{tabular}{llll}
\hline Diagnosis & \multicolumn{3}{l}{ Visual acuity } \\
\cline { 2 - 4 } & $\mathbf{2 0 / 2 0 - 2 0 / 4 0}$ & $\mathbf{2 0 / 5 0 - 2 0 / 2 0 0}$ & $\leq \mathbf{2 0 / 2 0 0}$ \\
\hline AU associated with & $10(91 \%)$ & $\mathrm{I}(\mathbf{9 \%})$ & - \\
HLA-B27 & & & \\
Fuchs uveitis syndrome & $10(72 \%)$ & $\mathrm{I}(\mathbf{7 \%})$ & $3(2 \mathrm{I} \%)$ \\
AU associated with HSV & $4(40 \%)$ & $3(30 \%)$ & $3(30 \%)$ \\
Behcet's uveitis & $6(86 \%)$ & $\mathrm{I}(14 \%)$ & - \\
Undetermined & $18(72 \%)$ & $6(24 \%)$ & $\mathrm{I}(4 \%)$ \\
\hline
\end{tabular}

Abbreviations: $\mathrm{AU}$, anterior uveitis; HLA, human leukocyte antigen; HSV, herpes simplex virus. the referral characteristics of centers that participated in that multicenter study. In Turkey, patients with Behcet's disease have been mostly followed up in university clinics, which may be related to overestimated ratios of Behcet's disease among anterior uveitis. In the present study, only $6.6 \%$ of patients were seen by an ophthalmologist before referral, the majority of whom were habitants of Umraniye county and were seen by the study clinic's ophthalmology department first. Additionally, Kazokoglu et al related their high percentage of anterior uveitis among patients with Behcet's disease to inadequate comprehensive examination of the posterior vitreous, which may lead to posterior segment involvement being overlooked. Therefore, the data reported in the present study may show more reliable incidence. In the present study, anterior uveitis associated with HLA-B27 was seen more often than reported in previous studies from Turkey. ${ }^{3,18}$ This may be due to the fact that, unlike the previous studies, the HLA-B27 typing test was performed on all patients with nongranulomatous and noninfectious uveitis.

The high frequency of noninfectious anterior uveitis, including anterior uveitis associated with HLA-B27 and FUS, in the present study was found to be similar to that reported by Cimino et al from Italy, ${ }^{4}$ Jakob et al from Germany, ${ }^{8}$ and Soheilian et al from Iran. ${ }^{5}$ Of the total 75 patients, $13(17.3 \%)$ were diagnosed as infectious anterior uveitis. This finding was similar to that found in the studies from Italy, Germany, and Iran, which ranged between 7\%-19\%. However, infectious anterior uveitis was predominantly seen in studies from Saudi Arabia, India, and Tunisia, with percentages up to $35 \%$ reported. ${ }^{6,7,17}$

At initial presentation, $8.5 \%$ of the eyes had visual acuity less than 20/200. The most common causes were mature cataract formation associated with FUS and corneal scars associated with HSV uveitis. In previous reports, Kazokoglu et al reported rates of visual acuity less than $20 / 200$ as $14 \%{ }^{3}$ and Oruc et al reported them as $18 \%{ }^{19}$

\section{Conclusion}

FUS and anterior uveitis associated with HLA-B27 were the most common diagnoses among anterior uveitis. Unlike other reports, only a small percentage of the patients in this study were referrals. Therefore, this study presents a more reliable incidence of anterior uveitis. Since specific ocular and systemic etiology were established in $72 \%$ of the cases, all anterior uveitis cases deserve further investigation. With an insistent approach, the causes of anterior uveitis could be expected in the majority of cases. 


\section{Disclosure}

The authors report no conflicts of interest in this work.

\section{References}

1. Whitcup SM. Anterior uveitis. In: Nussenblatt RB, Whitcup SM, editors. Uveitis: Fundamentals and Clinical Practice. 3rd ed. Philadelphia, PA: Mosby; 2004:273-286.

2. Ozdamar Y, Berker N, Elgin U, Ekmen R, Ozkan S, Karakaya J. The etiologic and demographic features of Behçet and non Behçet uveitis. Turkiye Klinikleri J Ophthalmol. 2010;19(2):94-98. Turkish.

3. Kazokoglu H, Onal S, Tugal-Tutkun I, et al. Demographic and clinical features of uveitis in tertiary centers in Turkey. Ophthalmic Epidemiol. 2008;15(5):285-293.

4. Cimino L, Aldigeri R, Salvarani C, et al. The causes of uveitis in a referral centre of Northern Italy. Int Ophthalmol. 2010;30(5):521-519.

5. Soheilian M, Heidari K, Yazdani S, Shahsavari M, Ahmadieh H, Dehghan M. Patterns of uveitis in a tertiary eye care center in Iran. Ocul Immunol Inflamm. 2004;12(4):297-310.

6. Islam SM, Tabbara KF. Causes of uveitis at The Eye Center in Saudi Arabia: a retrospective review. Ophthalmic Epidemiol. 2002;9(4): 239-249.

7. Singh R, Gupta V, Gupta A. Pattern of uveitis in a referral eye clinic in North India. Indian J Ophthalmol. 2004;52(2):121-125.

8. Jakob E, Reuland MS, Mackensen F, et al. Uveitis subtypes in a German interdisciplinary uveitis center - analysis of 1916 patients. J Rheumatol. 2009;36(1):127-136.

9. Herbort CP. Appraisal, work-up and diagnosis of anterior uveitis: a practical approach. Middle East Afr J Ophthalmol. 2009;16(4):159-167.
10. Jabs DA, Nussenblatt RB, Rosenbaum JT; Standardization of Uveitis Nomenclature (SUN) Working Group. Standardization of uveitis nomenclature for reporting clinical data. Results of the First International Workshop. Am J Ophthalmol. 2005;140(3):509-516.

11. International Study Group for Behcet's disease. Criteria for diagnosis of Behcet's disease. Lancet. 1990;335(8697):1078-1080.

12. Siverio CD Jr, Imai Y, Cunnigham ET Jr. Diagnosis and management of herpetic anterior uveitis. Int Ophthalmol Clin. 2002;42(1):43-48.

13. Tugal-Tutkun I, Guney-Tefekli E, Kamaci-Duman F, Corum I. A crosssectional and longitudinal study of Fuchs uveitis syndrome in Turkish patients. Am J Ophthalmol. 2009;148(4):510-515.

14. Tugal-Tutkun I, Araz B, Taskapili M, et al. Bilateral acute depigmentation of the iris: report of 26 new cases and four-year follow-up of two patients. Ophthalmology. 2009;116(8):1552-1557.

15. Herbort CP, Rao NA, Mochizuki M. International criteria for the diagnosis of ocular sarcoidosis: results of the first International Workshop on Ocular Sarcoidosis (IWOS). Ocul Immunol Inflamm. 2009;17(3): 160-169.

16. Yang $\mathrm{P}$, Zhang Z, Zhou H, et al. Clinical patterns and characteristics of uveitis in a tertiary center for uveitis in China. Curr Eye Res. 2005; 30(11):943-948.

17. Khairallah M, Yahia SB, Ladjimi A, et al. Pattern of uveitis in a referral centre in Tunisia, North Africa. Eye (Lond). 2007;21(1):33-39.

18. Sengun A, Karadag R, Karakurt A, Saricaoglu MS, Abdik O, Hasiripi H. Causes of uveitis in a referral hospital in Ankara, Turkey. Ocul Immunol Inflamm. 2005;13(1):45-50.

19. Oruc S, Kaplan AD, Galen M, Kaplan HJ. Uveitis referral pattern in a Midwest university eye center. Ocul Immunol Inflamm. 2003; 11(4):287-298.
Clinical Ophthalmology

\section{Publish your work in this journal}

Clinical Ophthalmology is an international, peer-reviewed journal covering all subspecialties within ophthalmology. Key topics include: Optometry; Visual science; Pharmacology and drug therapy in eye diseases; Basic Sciences; Primary and Secondary eye care; Patien Safety and Quality of Care Improvements. This journal is indexed on

Submit your manuscript here: http://www.dovepress.com/clinical-ophthalmology-journal

\section{Dovepress}

PubMed Central and CAS, and is the official journal of The Society of Clinical Ophthalmology (SCO). The manuscript management system is completely online and includes a very quick and fair peer-review system, which is all easy to use. Visit http://www.dovepress.com/ testimonials.php to read real quotes from published authors. 